\title{
Plea for justice when returning criminal cases to prosecutor by cassation court
}

\author{
Olga Vyacheslavovna Yevstigneyeva* \\ The First Cassation Court of General Jurisdiction, Saratov, Russia
}

\begin{abstract}
Pre-requisites of the research are the establishment of cassation courts of general jurisdiction in Russia, as well as no clear procedure in the Russian Federation Criminal Procedure Code for returning criminal cases to the prosecutor by the cassation court upon the grounds causing the impaired position of the convict (or acquitted person). The research purpose is to formulate requirements based on the principle of justice to the legal institute of returning criminal cases to the prosecutor by the cassation court for circumstances showing the need to impair the position of the convict (or acquitted person). The Methods are abstraction, analysis and synthesis, induction and deduction, modeling, ascending from abstract to concrete. The article substantiates that the grounds to return a criminal case to the prosecutor provided for in the Russian Federation Criminal Procedure Code causing remission of a sentence under a cassation procedure represent a type of material breaches of criminal procedure law that affect the outcome of the case. When such circumstances cause an impaired position of the convict (or acquitted person), they must comply with the requirements of justice.

Keywords: grounds for remission or change of the sentence by the cassation court, justice, balance of private and public interests
\end{abstract}

\section{Introduction}

The current Russian Federation Criminal Procedure Code (RF CPC) subdivides grounds for reversal or change of the judgment under a cassation procedure into circumstances improving (Part 1, Article 401.13 RF CPC) or impairing the position of the convict (Article 401.6 RF CPC). The latter include breaches of law that have affected the case outcome and that distort the essence of justice and meaning of the sentence as an act of justice.

One of the cassation grounds set out in Article 401.15 RF CPC that the legislator seems not to relate to a possibility of the convict's or acquitted person's position being impaired (since these grounds are not directly given in Article 401.6 RF CPC as the ones causing impairment) are circumstances given in Part 1 and Clause 1, Part 1.2, Article 237 RF CPC and causing the criminal case to be returned to the prosecutor. The establishment of these cassation grounds and of cassation courts of general jurisdiction in Russia aggravates the scientific discussion of the concept of material breaches of law causing reversal or change of the judgment under a cassation procedure [1].

\footnotetext{
* Corresponding author: evstig-olga@yandex.ru
} 
Various aspects of cassation court development in recent years are actively discussed both in Russia and other European countries [2]. There is a viewpoint in the scientific discussion concerning this issue stating that the stability of a res judicata sentence does not substantiate support to the sentence with serious legal and actual mistakes even if it is final [3].

Russian procedural scientists note that grounds for reversal of effective judgments shall include infringement of a right to a fair trial as given in Article 6 of the Convention for the Protection of Human Rights and Fundamental Freedoms and guaranteed by Article 10 of the Universal Declaration of Human Rights, Article 14 of the Covenant on Civil and Political Rights [4].

Moreover, during the inspection of judgments ruled by a higher court, the overall justice of the proceedings must be evaluated [5], which is inseparably related to establishing an accurate balance between obligations to victims and responsibility to the society and rights of the accused [6].

Ensuring procedural justice in criminal proceedings is very important and goes far beyond the scope of a specific criminal legal conflict. The studies have shown that if people believe they were treated fairly, they will more likely think that courts have a moral right to take decisions in arguable issues and, therefore, they will more likely submit to these judgments [7]. It was found that the main issue that courts face is how to act in various circumstances to which procedural justice is applied [8].

Russian procedural scientists have expressed an opinion that it is impossible to formalize the scope of material breaches [9]. At the same time, it is noted that because of no clear list of such grounds in the law, there is plenty of room for judicial discretion [10].

It should be noted that the law still has a number of unconditional grounds to reverse a judgment and return the criminal case to the prosecutor that do not require the use of judicial discretion. They include disclosure of information proving that the person fails to comply with provisions and obligations set out in the pretrial settlement on collaboration; elimination of circumstances given in Part 5, Article 247, RF CPC provided there is a solicitation of the convict or his/her lawyer $[11,12]$.

Scientific literature gives a justified opinion that according to the grounds given in Parts 1 and 1.2, Article 237 RF CPC, the cassation court faces the issue of fact when it discusses the issue of the onset of new socially hazardous circumstances [13-16].

Taking into account that circumstances of returning a criminal case to the prosecutor provided by Article $237 \mathrm{RF}$ CPC are formulated for plenary proceedings, some scientists believe it is not correct to refer to them as to individual grounds for reversal of the judgment, defining, enacting and returning the case to the prosecutor under a cassation procedure [17].

Other authors were positive when these cassation grounds appeared in the language of law and underlined that it was caused by the need to protect the rights of the accused (convicted or acquitted) and the victim, as well as private and public interests that require a just a judgment rather than a formal one [18].

The author's scientific hypothesis is that when the grounds to return the criminal case to the prosecutor cause the convict (or acquitted person) position to impair, they must comply with the requirements set out in Article 401.6 RF CPC. A different approach contradicts the principle of justice in criminal proceedings.

\section{Methods}

To achieve this goal, such theoretic methods of cognition as abstracting, analysis and synthesis, induction and deduction, modeling, ascending from abstract to concrete will be used. 


\section{Results}

Requirements are formulated, which must be taken into account in law-enforcement practice when returning the criminal case to the prosecutor by a cassation court and which ensure not only correction of clamant judicial mistakes distorting the essence of justice and meaning of the sentence as an act of justice but also a just balance of interests of parties and public interests of justice in criminal proceedings.

\section{Discussion}

According to the definition of the Russian Federation Constitutional Court as of June 6, 2017, No. 1166-O, the position of the convict (or acquitted person) can be impaired when returning the criminal case to the prosecutor by a cassation court. The analysis of the list of situations given in Part 1 and Clause 1, Part 1.2, Article 237 RF CPC shows that the convict's position can be impaired not for all grounds but only for those where such opportunity of position impairment of the person subject to such criminal prosecution is provided by Article $237 \mathrm{RF}$ CPC (Clauses 1, 6, Part 1, Article 237 RF CPC).

According to the definition of the Russian Federation Constitutional Court as of November 24, 2016, No. 2585-O, when a criminal case is returned to the prosecutor, the provisions of Article 401.6 RF CPC concerning the possible impaired condition of the convict (or acquitted person) during a year after the judgment becomes effective shall be taken into account. This position is completely supported by the Russian Federation Supreme Court in its definition as of October 8, 2019, No. 69-UD19-16.

Based on the rules common for cassation proceedings and formulated in Clause 18 of the Supreme Court Plenum Decree as of June 25, 2019, No. 19, the cassation court may return the case to the prosecutor upon the grounds impairing the position of the convict (or acquitted person) only under a cassation appeal of the victim or a cassation representation by the procurator if they directly indicate a respective argument.

Moreover, due to Article 401.15 RF CPC, the grounds causing the criminal case to be returned to the prosecutor require their evaluation in terms of materiality for using by the cassation court. For example, such a circumstance causing the criminal case to be returned to the prosecutor as grounds for combining criminal cases (Clause 4, Part 1, Article 237 RF CPC), does not meet the materiality criterion. Individual proceedings of different criminal cases that have already taken place can hardly be deemed as a blatant judicial mistake, the discovery of which is related by the legislator to the need to reverse the effective judgment.

As for the criminal case return to the prosecutor for applying the law of a graver offense (Clause 6, Part 1, Article 237 RF CPC), and due to the onset of new socially hazardous consequences of the action incriminated to the accused (Clause 1, Part 1.2, Article 237 RF CPC), the author believes that these circumstances fully meet the materiality criterion and can affect the final judgment.

\section{Conclusion}

The procedure of taking a decision on the reversal of a sentence and returning the legal case to the prosecutor upon the grounds impairing the position of the convict (or acquitted person) must comply with the following requirements in order to be deemed just:

1. Making such a judgment must be permitted only during a year after the sentence becomes effective; 
2. This judgment must not be made at the court or defense initiative. It must be initiated by the prosecution only (when a respective argument is contained in the cassation appeal of the victim or cessation representation by the prosecutor);

3. The list of grounds causing the convict's position to impair is set by law (Clause 6, Part 1, Article 237 RF CPC, Clause 6, Part 1.2, Article 237 RF CPC) and cannot be subject to broad interpretation;

4. These grounds must indicate not only the infringement of interests of the victim but also a breach of public interests of justice;

5. Failure to correct such mistakes in case there is a respective argument must indicate the distortion of the essence of justice and meaning of the sentence as an act of justice, decrease the public trust in the judicial system, and prevent from regarding justice as fair.

\section{References}

1. V.S. Zhelonkin, Vestnik of the Omsk Law Academy, 14(2), 98-103 (2017)

2. F. Ferrand, The French court of cassation: On the threshold of a quiet revolution?, in C. van Rhee, Y. Fu (eds.), Supreme Courts in Transition in China and the West. Ius Gentium: Comparative Perspectives on Law and Justice, vol. 59, 175-206 (Springer, Cham, 2017). https://doi.org/10.1007/978-3-319-52344-6_9

3. V. Brutaru, Influence of the constitutional court and high court of cassation and justice jurisprudence on extraordinary appeals (appeal in cassation). http://doi.org/10.2139/ssrn.3614457

4. I.S. Dikarev, Nadzorno-kassatsionnaya forma peresmotra sudebnykh reshenii v ugolovnom protsesse: monografiya [Review Cassation Form of Revising Judgments in Criminal Process: Monograph] (Volga State University Publishing House, Volgograd, 2016)

5. J.H. Dingfelder Stone, The right to a fair trial, in Court Interpreters and Fair Trials, 103-158 (Palgrave Macmillan, Cham, 2018). https://doi.org/10.1007/978-3-319-753553_4

6. Ch.J. Hynes, Fordham Urban Law J. 20(3), 419-430 (1993). Accessed on: March 16, 2021. [Online]. Available: https://ir.lawnet.fordham.edu/ulj/vol20/iss3/3

7. E. Gold LaGratta, Ph. Bowen, To be fair: procedural fairness in courts. Report (November 2014). Accessed on: March 16, 2021. [Online]. Available: https://justiceinnovation.org/publications/be-fair-procedural-fairness-courts

8. B. Dyer, Monash University Law Review 19(1), 188-191 (1993)

9. L.V. Golovko (ed.), Kurs ugolovnogo protsessa [Course of Criminal Procedure] (Statut, Moscow, 2016)

10. A.R. Belkin, Criminal Judicial Proceeding, 3, 25-29 (2014)

11. M.T. Ashirbekova, V.N. Troneva, Magistrate Judge, 10, 30-35 (2017)

12. A.D. Proshlaykov, M.V. Merzlyakova, Issues of Law, 2, 158 (2015)

13. I.S. Dikarev, Legality, 1, 47 (2014)

14. M.T. Ashirbekova, Criminal Judicial Proceeding, 3, 9 (2014)

15. M.A. Khokhryakov, Eurasian Union of Scientists, 12-4, 129 (2015)

16. V.A. Vdovin, Russian Laws: Experience, Analysis, Practice, 1, 61-64 (2017)

17. V.V. Kalnitsky, T.V. Kuryakhova, Criminal Law, 3, 110-115 (2016)

18. A.R. Belkin, Criminal Judicial Proceeding 3, 32-47 (2019) 